\title{
Sport and exercise medicine: bringing you up to date
}

\author{
Polly Baker, ${ }^{1}$ Eleanor Tillett ${ }^{2}$
}

Welcome to the 2019 British Association of Sport \& Exercise Medicine (BASEM) issue of the British Journal of Sports Medicine. Bringing this issue together has been an enjoyable experience allowing us as editors to peruse topics in the spotlight for those working within sport and exercise medicine. As a specialty, we have always encompassed a broad subject area from exercise prescription to musculoskeletal medicine and beyond. The governance of our specialty is also gaining increasing prominence both in terms of setting standards for those employed within the specialty and also in the development of position statements for a variety of conditions related to sports medicine. Our role in health protection is highlighted by several articles including Sean Carmody's editorial on our duty of care to retiring footballers (see page 788) and Aneil Malhotra's research into emergency response facilities in professional football clubs (see page 813 ).

\section{WHAT'S NEW FOR PHYSICAL ACTIVITY?} This issue is no exception in terms of breadth of topics covered. Some key themes include the importance and promotion of physical activity and the integrated and/or interdisciplinary approach to the management of the athlete and patient. The key role of physical activity in mental health was recently addressed in our BASEM Spring Conference. We had some great speakers including Dr Simon Rosenbaum and Dr Brendon Stubbs, who talked us through the evidence demonstrating the positive benefits of exercise in preventing and managing mental health conditions. They discussed the transdiagnostic benefits of exercise and to quote Simon 'the biceps don't care what the DSM says'. Please do watch out for the follow up podcast.

It is not only that physical activity is good for you but also that sedentary

\footnotetext{
'University of Brighton, Brighton, UK

${ }^{2}$ Division of Surgery and Interventional Science, University College London, London, UK
}

Correspondence to Dr Eleanor Tillett, Division of Surgery and Interventional Science, University College London, London WC1E 6AU, UK; e.tillett@ucl.ac.uk activity is bad for you. The most recent WHO Global Action plan is brought into the limelight by Dr Andrew Murray, who calls to all those involved in health to help deliver and sustain this important movement (see page 794), and in Laurien Buffart's review, we learn more about what moderates exercise effects in cancer patients (see page 812).

\section{TEAM PLAYERS}

Another subject focus within this issue is the influence and importance of an integrated approach to care delivered in a musculoskeletal or sport setting. An integrated approach encompasses a holistic view of the patient, taking into account their musculoskeletal injury psychosocial factors contributing to its presentation. Its relevance is discussed within Dr O'Keeffe's editorial, Psychosocial Factors in Low Back Pain: Letting Go of Our Misconceptions Can Help Management (see page 793). Dr O'Keeffe is part of the research team driving the use of cognitive function therapy in the treatment of low back pain with the aim to reduce the burden it currently presents globally. We recommend searching out some of her other articles to expand on this further.

Its use within the elite setting is also discussed in Lauren Burns's qualitative review of Lifestyles and Mindsets of Olympic Paralympic and World Champions (see page 818 ). It poses the question as to whether an integrated approach is key to elite performance. Part of an integrated approach can include the utilisation of multidisciplinary team. This approach is commonplace for a port and exercise medicine practitioner who has the breadth of knowledge across primary care, musculoskeletal and pain medicine, as well as experience working within multidisciplinary teams. This, perhaps, 'unique selling point' of sport and exercise medicine is often overlooked in research, and its great to see this covered in a number of articles within this issue.

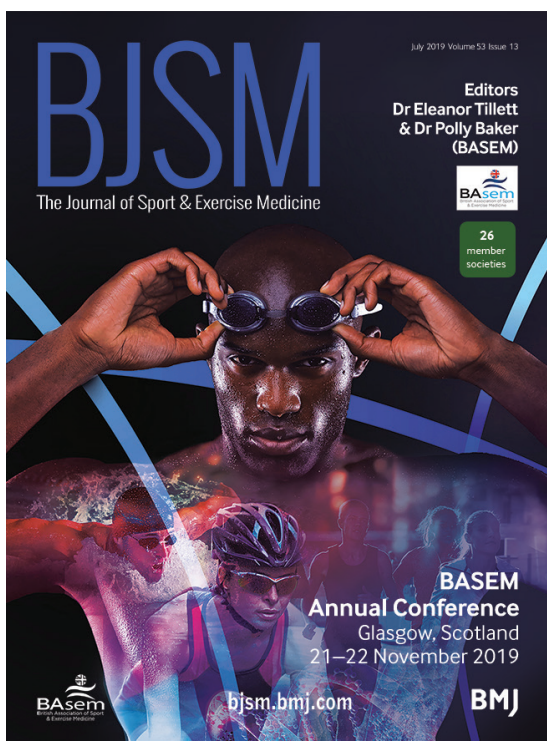

\section{AND SO TO GLASGOW...}

BASEM's annual conference will be in Glasgow this year on 21 and 22 November. As with this issue, the topic coverage is broad with musculoskeletal, exercise and team care streams. The final programme will be advertised shortly, but it promises to spark lots of debate including 'Opening Pandora's Box' of genetic testing, gene editing and gender fluidity. As always, there will be the opportunity to submit your own research abstracts for poster and podium presentation, and we are pleased to highlight the prize winners from 2018 in this issue.

We look forward to seeing lots of you there.

Contributors Both authors contributed to the writing of this article.

Funding The authors have not declared a specific grant for this research from any funding agency in the public, commercial or not-for-profit sectors.

Competing interests None declared.

Patient consent for publication Not required.

Provenance and peer review Commissioned; internally peer reviewed.

(C) Author(s) (or their employer(s)) 2019. No commercial re-use. See rights and permissions. Published by BMJ.

$$
\text { A) Check for updates }
$$

To cite Baker P, Tillett E. Br J Sports Med 2019;53:787.

Accepted 20 May 2019

Br J Sports Med 2019;53:787

doi:10.1136/bjsports-2019-101079 